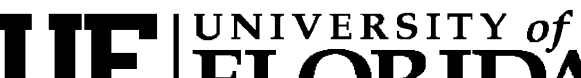 FLORIDA \\ IFAS Extension
}

\section{Greenhouse Gas Mitigation in Forest and Agricultural Lands: Carbon Sequestration ${ }^{1}$}

\section{Solomon G. Haile, Clyde W. Fraisse, Vimala D. Nair, and P.K. Ramachandran Nair ${ }^{2}$ \\ Climate has regularly changed since the Earth \\ What is greenhouse gas?} was formed. However, many members of the scientific community attribute current climate changes to increasing atmospheric concentrations of greenhouse gases (GHGs), caused by human activities. In the last half of the 20th century, carbon dioxide $\left(\mathrm{CO}_{2}\right)$ was the first GHG conclusively demonstrated to be increasing in the atmosphere. At the current rate of emission, atmospheric $\mathrm{CO}_{2}$ is projected to double by the end of the 21 st century. Climate change mitigation will require reducing GHG emissions, as well as removing $\mathrm{CO}_{2}$ from the atmosphere and sequestering it in different reserves. This document addresses some basic questions regarding the prospects of carbon (C) sequestration in forest and agricultural lands in the United States in general and Florida in particular. Specifically, it examines the $\mathrm{C}$ sequestration potential of different land management practices that could play a role in GHG mitigation strategies.
Greenhouse gas is a collective name given to atmospheric gases that are mostly of natural origin, including water $\left(\mathrm{H}_{2} \mathrm{O}\right)$ vapor, $\mathrm{CO}_{2}$, carbon monoxide $(\mathrm{CO})$, methane $\left(\mathrm{CH}_{4}\right)$, nitrous oxide $\left(\mathrm{N}_{2} \mathrm{O}\right)$, nitrogen oxide ( $\mathrm{NO})$, nitrogen dioxide $\left(\mathrm{NO}_{2}\right)$, and ozone $\left(\mathrm{O}_{3}\right)$. GHGs produced by human activities include compounds of hydrofluorocarbons, perfluorocarbons, and sulfur hexafluoride.

\section{What is the greenhouse effect?}

Energy from the sun drives the earth's climate. Atmospheric GHGs trap some of this energy, creating a natural greenhouse effect. The temperature in a greenhouse is warmer than ambient temperature because the glass that covers the greenhouse does not allow long-wave radiation to be emitted outward. Greenhouse gases in the atmosphere, especially water vapor, $\mathrm{CO}_{2}, \mathrm{O}_{3}$, and $\mathrm{CH}_{4}$, act like the glass in a greenhouse to trap infrared radiation in a similar manner. The extent to which atmospheric temperature is elevated depends on the concentration of GHGs in the atmosphere (Lal et al., 1999). Water vapor,

1. This document is AE435, one of a series of the Agricultural and Biological Engineering Department, Florida Cooperative Extension Service, Institute of Food and Agricultural Sciences, University of Florida. Original publication date September 2008. Visit the EDIS Web Site at http://edis.ifas.ufl.edu.

2. Solomon G. Haile, postdoctoral research associate, Soil and Water Science Department; Clyde W. Fraisse, assistant professor, Agricultural and Biological Engineering Department, Vimala D. Nair, research associate professor, Soil and Water Science Department; P.K. Ramachandran Nair, professor, School of Forest Resources and Conservation; Florida Cooperative Extension Service, Institute of Food and Agricultural Sciences, University of Florida, Gainesville, FL 32611

The Institute of Food and Agricultural Sciences (IFAS) is an Equal Opportunity Institution authorized to provide research, educational information and other services only to individuals and institutions that function with non-discrimination with respect to race, creed, color, religion, age, disability, sex, sexual orientation, marital status, national origin, political opinions or affiliations. U.S. Department of Agriculture, Cooperative Extension Service, University of Florida, IFAS, Florida A. \& M. University Cooperative Extension Program, and Boards of County Commissioners Cooperating. Larry Arrington, Dean 
followed by $\mathrm{CO}_{2}$, is the most abundant GHG in the atmosphere. However, changes in water vapor concentration are also considered to be a result of climate response related to the warming of the atmosphere rather than a direct result of industrialization. Methane, $\mathrm{NO}, \mathrm{O}_{3}$, and several other gases present in the atmosphere in small amounts also contribute to the greenhouse effect (IPCC 2007).

Several human-induced (anthropogenic) activities increase atmospheric concentrations of GHGs, particularly $\mathrm{CO}_{2}$. Atmospheric $\mathrm{CO}_{2}$ concentration increased from $280 \mathrm{ppm}$ (parts per million) in the $1950 \mathrm{~s}$ to $379 \mathrm{ppm}$ in 2005 . The annual rate of increase was higher over the past 10 years (1995 - 2005 average: 1.9 ppm per year) than it has been since the beginning of continuous direct atmospheric measurements (1960 - 2005: 1.4 ppm) (IPCC 2007).

From approximately $1850-1899$ to $2001-2005$, total temperature increased an average of $1.37^{\circ} \mathrm{F}$, with a range between $1.03^{\circ} \mathrm{F}$ and $1.71^{\circ} \mathrm{F}$ (IPCC 2007). While the resulting increase in heat-trapping ability for a given concentration of GHGs can be predicted with precision, the ultimate impact on climate can not. Projections of climate change are based on complex models that describe the circulation of air and ocean currents, as well as how energy is transported within the climate system. Recent model simulations suggest that global surface temperature could increase an average of $1.0-6.4^{\circ} \mathrm{F}$ by 2100 (IPCC, 2007). The ranges of temperature projections are larger because model simulations increasingly depend on specific emissions scenarios. Between 2000 and 2030, the global GHG emissions are projected to increase by 25 to $90 \%$ (IPCC 2000b).

\section{What is carbon sequestration?}

It is widely believed that reducing the atmospheric concentration of $\mathrm{CO}_{2}$ could reduce future climate-related damage and would be more beneficial than costly. Options for achieving this goal include reducing future emissions as well as sequestering $\mathrm{CO}_{2}$ that has already accumulated. Carbon sequestration involves "removing $\mathrm{C}$ from the atmosphere and depositing it in a reservoir" (UNFCCC 2006).
Carbon can be sequestered in two major ways: biological and geological. Geological sequestration, which has a fairly large technological potential, has not yet been demonstrated on a scale anticipated to mitigate $\mathrm{CO}_{2}$ emissions. It is also more costly. Thus current discussions are focused on biological methods for sequestering $\mathrm{C}$.

\section{What is biological carbon sequestration?}

Biological $\mathrm{C}$ sequestration transfers $\mathrm{C}$ (from $\mathrm{CO}_{2}$ ) in the atmosphere to biomass through photosynthesis and ultimately stores it in plants (foliage, wood, and roots) and soils. Biological sequestration encompasses various ways of using agricultural and forest land to enhance the natural storage of atmospheric $\mathrm{CO}_{2}$. Examples include planting or preserving trees, altering crop production practices, planting vegetation in areas prone to soil erosion, and changing the way grazing lands are managed. When forests, croplands, and grazing lands sequester C, they are referred to as C "sinks".

Forest and agricultural lands have received considerable attention as potential $\mathrm{C}$ sinks. In most cases, atmospheric $\mathrm{CO}_{2}$ removal through $\mathrm{C}$ sequestration exceeds $\mathrm{CO}_{2}$ emissions from these land-use types, particularly from forests. According to the U.S. GHG Inventory 2006 (EPA 2008), land use, land-use change, and forestry activities comprise a net sequestration of 883.7 million metric tons $(\mathrm{mmt})$ of $\mathrm{CO}_{2}$-Eq. This represents an offset of approximately 14.8 percent of total U.S. $\mathrm{CO}_{2}$ emissions, or $12.5 \%$ of total greenhouse gas emissions. Over $84 \%$ of this net sink occurs on forest lands. Between 1990 and 2006, total land use, land-use change, and forestry net $\mathrm{C}$ flux resulted in a $20 \%$ increase in $\mathrm{CO}_{2}$ sequestration, primarily due to an increase in the rate of net $\mathrm{C}$ accumulation in forest $\mathrm{C}$ stocks, particularly in aboveground and belowground tree biomass. In contrast, the agriculture sector is a net emitter of GHGs (EPA 2008). In 2006, $\mathrm{CH}_{4}$ and $\mathrm{N}_{2} \mathrm{O}$ were the primary greenhouse gases emitted by agricultural activities. Methane emissions from enteric fermentation and manure management represented about $23 \%$ and $7 \%$ of total $\mathrm{CH}_{4}$ emissions from anthropogenic activities, respectively. 
The use of biomass and biofuels to replace $\mathrm{CO}_{2}$ emitting petroleum based fuels as energy sources has great potential for mitigating GHG emissions in the southeastern United States (EPA 2005). Over the coming decades, Florida forestry and agriculture could significantly offset and reduce the projected emission increases in the state. Florida's forest cover declined 36\% between 1945 and 2002 (although it still covers $43 \%$ of the 34.3 million land acres); during the same period, crop and pasture lands increased by $22 \%$ (USDA/ERS, 2006). Improved management of forests and agricultural lands could provide an effective tool to help stabilize atmospheric GHGs.

\section{What are the major pools of sequestered carbon in agricultural and forest lands?}

In a forest ecosystem, $\mathrm{C}$ sequestration occurs in four components of the system: soil, trees, forest floor, and understory vegetation. The total amount sequestered in each part varies greatly depending on the region, type and age of the forest, the quality of the site, and land use history. On average, the soil and above-ground parts of trees hold the major portions, roughly $60 \%$ and $30 \%$ respectively, of the total C stored in a forest; the rest is mostly in forest litter $(9 \%)$ and understory vegetation (1\%) (Birdsey, 1992).

According to the IPCC (2000), potential increases in $\mathrm{C}$ storage may occur in agricultural and forest lands via (1) improved management within a land use, (2) conversion to a land use with higher $\mathrm{C}$ stocks, or (3) increased C storage in harvested products. Achieving those increases will vary according to the new land use and management practices, net emissions of GHGs associated with additional management activities, and land use policies. The scientific literature to evaluate diverse scenarios for increasing $\mathrm{C}$ storage is currently limited. However, one such scenario, presented in Table 1, illustrates the potential range for $\mathrm{C}$ stock increases through some broadly defined activities. It provides data and information on $\mathrm{C}$ stock changes for some candidate activities for the year 2010. The greatest potential for $\mathrm{C}$ sequestration occurs when land-use becomes more sustainable, with the largest dividend estimated when arable land is changed to agroforestry (Table 1).

Integrated production systems like silvopastoral agroforestry systems, where trees were integrated into pasture animal production, can increase net $\mathrm{C}$ storage. When both the tree and grass components are well-managed, an increase in net $\mathrm{C}$ storage compared with pasture or forest alone can be achieved. Sharrow and Ismail (2004) reported from their studies in Oregon that the silvopastoral system accumulated approximately $299 \mathrm{~kg}$ acre $^{-1} \mathrm{yr}^{-1}$ more $\mathrm{C}$ than forests and $210 \mathrm{~kg} \mathrm{acre}^{-1} \mathrm{yr}^{-1}$ more $\mathrm{C}$ than pastures. The agroforests were silvopastures of 11-yr-old Douglas fir (Pseudotsuga menziesii) with perennial ryegrass (Lolium perenne) and clover (Trifolium sp.) pasture. The combination of pasture and trees also stored 214 $\mathrm{kg}$ acre $^{-1}$ more $\mathrm{N}$ aboveground than the forest, and the pasture stored $486 \mathrm{~kg} \mathrm{~N}$ acre $^{-1}$ more $\mathrm{N}$ aboveground than the forest. More efficient sharing of site resources between tree and pasture plants and microclimate modification by trees may increase overall net production of phytomass available for storage (Table 2).

\section{What practices could be used as strategies for enhancing carbon sequestration?}

Forestry practices:

\section{Afforestation/reforestation of marginal cropland and pasture.}

Planting trees on land previously used for other purposes could result in substantial gains in $\mathrm{C}$ storage in biomass and soils. Estimates show that afforested lands raise annual $\mathrm{C}$ sequestration by the equivalent of 2.2 to 9.5 metric tons of $\mathrm{CO}_{2}$ acre $^{-1}$ for 120 years; (Birdsey, 1996). For reforestation (planting trees on land recently devoted to forestry, such as severely burned areas), the increase is smaller (4 to 28 metric tons acre ${ }^{-1} \mathrm{CO}_{2}$-eq sequestration for the same time frame).

\section{Improved forest management.}

Carbon storage can also be improved by changing silvicultural practices. Since these practices are usually developed and applied for purposes other 
Table 1. Global estimates of potential net change in carbon storage through improved management within land-use and change in land-use activities. Values shown are average rates during this period of accumulation.

\begin{tabular}{|c|c|c|c|c|}
\hline Additional Activities & $\begin{array}{l}\text { Total area } \\
\left(10^{6} \text { acre }\right)\end{array}$ & $\begin{array}{l}\text { Area under } \\
\text { activity } \mathrm{a}- \\
(\%)\end{array}$ & $\begin{array}{l}\text { Net annual change } \\
\text { (Metric tons of } \mathrm{CO}_{2} \\
\left.\text { acre }^{-1} \mathrm{yr}^{-1}\right)\end{array}$ & $\begin{array}{c}\text { Estimated net } \\
\text { change in } 2010\left(10^{6}\right. \\
\text { Metric tons of } \mathrm{CO}_{2} \\
\left.\mathrm{yr}^{-1}\right)\end{array}$ \\
\hline \multicolumn{5}{|c|}{ Improved management within land use } \\
\hline Cropland $\stackrel{\mathrm{b}}{-}$ & 3212 & 30 & 0.4 & 385 \\
\hline Forest land $\stackrel{c}{-}$ & 10008 & 10 & 0.6 & 600 \\
\hline Grazing land $\mathrm{d}$ & 8401 & 10 & 1 & 840 \\
\hline Agroforestry area $\mathrm{e}$ & 988 & 20 & 0.4 & 79 \\
\hline Urban land $\mathrm{f}$ & 247 & 5 & 0.4 & 5 \\
\hline \multicolumn{5}{|c|}{ Change in land use } \\
\hline Agroforestry ${ }^{g}$ & 1557 & 20 & 4.6 & 1432 \\
\hline Grassland ${ }^{\mathrm{h}}$ & 3707 & 3 & 1.2 & 133 \\
\hline Wetland restoration - & 568 & 5 & 0.6 & 17 \\
\hline
\end{tabular}

Table 2. Estimates of carbon dioxide sequestered in three different land-use systems in Oregon, USA

\begin{tabular}{|c|c|c|c|}
\hline \multirow[t]{2}{*}{ Compartment } & \multicolumn{3}{|c|}{ Metric tons of $\mathrm{CO}$ acre $^{-1}$} \\
\hline & Pasture & Agroforests & Plantation \\
\hline Tree & 0 & 18 & 10 \\
\hline Understory & 1 & 2 & 3 \\
\hline Soil $(0-45 \mathrm{~cm})$ & 152 & 142 & 137 \\
\hline Total & 154 & 162 & 150 \\
\hline
\end{tabular}

than $\mathrm{C}$ sequestration, it may be difficult to quantify the magnitude of increased total $\mathrm{C}$ storage when practices change. For instance, increasing timber growth will not necessarily increase biomass growth and soil C storage. Nevertheless, estimates of such increases range from 2.1 to 3.1 metric tons of $\mathrm{CO}_{2}$-eq acre ar $^{-1}$. Twenty to $45 \%$ of the $\mathrm{C}$ in the salable portion of harvested timber is sequestered in wood and paper products during their usable lives and afterwards in landfills (Gorte, 2007). Thus, increases in $\mathrm{C}$ from timber management do not have a fixed time horizon.

\section{Reduced conversion of forest land to non-forest use (Avoid deforestation).}

Conversion of forest land to non-forest use usually means permanent loss of all or a substantial part of live biomass and reduction of organic matter in soils and in the forest floor. Some $\mathrm{C}$ may be sequestered in wood products if the harvested biomass is utilized. Carbon dioxide and other GHGs are emitted when the remaining biomass and organic matter is burned or decomposed. Protecting and conserving forests should maintain or increase $\mathrm{C}$ 
pools in the short term. Carbon in wood and paper products remains sequestered and is emitted to varying degrees depending on how products are made, used, and disposed. Sequestration in products and uses can be increased by altered processing methods, shifts in products used, end-use durability, and landfill management. Sequestration in forests and products can be maximized by coordinated understanding of forest ecosystems and product utilization.

\section{Agricultural and grassland practices}

Compared with forests, above-ground biomass stocks in agricultural and grassland ecosystems are fairly small (typically less than 15 metric tons of $\mathrm{CO}_{2}$-eq acre $\left.^{-1}\right)$. Prospects for $\mathrm{C}$ sequestration in agricultural and grassland ecosystems are largely centered on the soil. Hence, strategies for increasing $\mathrm{C}$ stocks in these systems revolve around maximizing the amount of $\mathrm{C}$ that can be delivered to the soil and maximizing its residence time in the soil. Carbon sequestration in agricultural and grass lands can be enhanced by intensifying prime agricultural lands, land conservation, and restorations. These options include a variety of land use practices that could be adapted as best management practices by landowners.

Prospects for $\mathrm{C}$ sequestration in grasslands include (1) optimizing grazing intensity, because $\mathrm{C}$ accrual on optimally grazed lands is often greater than on non-grazed or over-grazed lands (Liebig et al. 2005); (2) increasing grass productivity through increased fertilization and improved soil quality; and (3) introducing grass species that are more productive or have higher $\mathrm{C}$ allocation to the roots.

In the case of croplands, $\mathrm{C}$ sequestration strategies include (1) improved agronomic practices that increase yield and generate higher crop residue; and (2) improved tillage and residue management such as reduced tillage, or no-till, that reduces soil disturbance, consequently reducing $\mathrm{C}$ losses through enhanced decomposition or soil erosion. Table 3 lists the various strategies that can be used for $\mathrm{C}$ sequestration in U.S. croplands. Lal et al. (1999) estimated that 302 to $763 \mathrm{mmt} \mathrm{CO}_{2}$-eq $\mathrm{yr}^{-1}$ could be sequestered in arable lands of the United States by adopting these improved practices, of which about $50 \%$ is due to conservation tillage and residue management, $6 \%$ to supplemental irrigation and water table management, and $25 \%$ to adoption of cropping systems.

The practices listed above, if adopted by Florida's agricultural and forestry sectors hold great potential to increase the rate of $\mathrm{C}$ sequestration in the state. However, further advances in developing cost-effective ways to monitor and quantify the amount of $\mathrm{C}$ sequestered in agricultural and forest lands is required. In addition, developing $\mathrm{C}$ best management practices (BMPs) that provide incentives for adopting strategies to enhance $\mathrm{C}$ sequestration is crucial. Eventually, these combined with the growing $\mathrm{C}$ market can lead to an increased contribution of agricultural and forest sectors to the mitigation of climate change.

\section{Lists of References}

Birdsey, R. A. 1992. Carbon storage and accumulation in United States forest ecosystems. General Technical Report W0-59. United States Department of Agriculture (USDA). Forest Service.

Birdsey, R. A. 1996. Regional estimates of timber volume and forest carbon for fully stocked timberland, average management after final clear-cut harvest. p. 309-334. In R.N. Sampson, and D. Hair. (eds.). Forests and global change: Vol. 2: Forest management opportunities for mitigating carbon emissions. American forests. Washington, D.C.

Gorte, R. W. 2007. Carbon sequestration in forests, Congressional Research Service (CRS) Report for Congress RL31432.

Intergovernmental Panel on Climate Change (IPCC). 2007. Climate change 2007: The physical science basis. Contribution of working group I to the fourth assessment report of the IPCC. [Solomon, S., D. Qin, M. Manning, Z. Chen, M. Marquis, K.B. Averyt, M. Tignor, and H.L. Miller (eds.)]. Cambridge University Press, Cambridge, United Kingdom, and New York, NY, USA.

IPCC. 2000a. Land use, land use change and forestry. Special report of the IPCC. Cambridge University Press, Cambridge, UK. 
IPCC. 2000b. Special report on emissions

scenarios. Cambridge University Press, Cambridge, United Kingdom and New York, NY, USA.

Lal, R., J.M. Kimble, R.F. Follett, and C.V. Cole. 1999. The potential of US cropland to sequester carbon, and mitigate the greenhouse effect. CRC Press LLC. Lewis publishers.

Liebig, M.A., J.A. Morgan, J.D. Reeder, B.H. Ellert, H.T. Gollany, and G.E. Schuman. 2005. Greenhouse gas contributions, and mitigation potential of agricultural practices in Northwestern USA, and Western Canada. Soil and tillage research. $83: 2552$.

Sharrow S.H., and S. Ismail. 2004. Carbon and nitrogen storage in agroforests, tree plantations, and pastures in western Oregon, USA. Agrofor. Syst.

60:123-130.

United Nations Framework Convention on Climate Change (UNFCCC) 2008. Essential background: Glossary of climate change acronyms. Available at http://unfccc.int/essential_background/glossary/items/ 3666.php Cited 08 May 2008.

United States Department of Energy (DOE).1999. Carbon sequestration: State of science. Draft report. Ch. 4: Carbon sequestration in terrestrial ecosystems. p.29.

United States Environmental Protection Agency. 2008. Inventory of U.S. Greenhouse Gas Emissions and Sinks: 1990-2006. EPA 430-R-08-005

United States Environmental Protection Agency. 2005. Greenhouse gas mitigation potential in US forestry and agriculture. EPA 430-R-05-006. 
Table 3. Strategies for increasing carbon $(C)$ sequestration using different land-management practices in croplands of the United States.

\begin{tabular}{lll}
\hline Mitigation option & Management practice & $\begin{array}{l}\text { Estimated potential } \\
\left.\left(\mathrm{mmt}^{-1} \mathrm{CO}_{2}-\mathrm{eq}_{\mathrm{yr}}\right)^{-1}\right)\end{array}$
\end{tabular}

A. Intensification of croplan
Conservation tillage, and residue
a. Conservation tillage
b. Crop residue, and other
biomass management
Irrigation/water management
a. Supplemental

a. Supplemental

b. Sub-irrigation on poorly drained soils Improved cropping systems

a. Fertilizer management

b. Organic measures, and by-products

c. Rotation winter cover crops

d. Summer fallow elimination

e. Management of rice straw

f. Idle land conversion to biofuel production management

Use no-till, minimum till, ridge till, or sod till on crop

88-147

land to decrease $C$ loss due to soil erosion and net mineralization, and to increase soil aggregation.

Select crops that produce sufficient quantities of residue, plant a cover crop, and/or leave crop residues on the soil surface.

Supplement with irrigation to increase biomass production, especially in dry areas; an increase of 2 to 5 times in biomass production could be attained.

Recycle drainage water during summer to improve moisture content and biomass yield.

Maintain soil fertility by adding manure and inorganic fertilizer when needed.

Apply organic manure or compost to increase soil C content.

Plant cover crops after harvesting. Examples in the

Southeast include crimson clover, hairy vetch, common vetch, crown vetch, alfalfa, lupines, arrow leaf clover, and red clover.

Replace summer fallow system with intensive cropping system to increase soil organic $\mathrm{C}$. Improve management of rice straw through compost, and mulch farming rather than burning.

Use available idle lands, and marginal croplands to produce biofuel.

\section{B. Land conversion and restoration}

Land-use conversion

a. Conservation reserve program (CRP), as a provision of the 1985 and 1990 Farm Bills.

Conversion buffers
c. Wetland reserve program (WRP)
Land/ soil restoration
a. Eroded land

Convert highly erodible (erosion rate 19.1 tons acre ${ }^{-1}$ or more) land from active crop production to permanent vegetative cover for a 10 -year period (e.g. tree plantation, growing cover crops).

Install vegetative strips, ranging from 5 to $50 \mathrm{~m}$ wide, along streams and agricultural lands to minimize soil erosion and the risk of transporting non-point source pollutants into the stream.

Restore, enhance, and protect wetlands through WRP to accumulate peat.

Restore moderately eroded crop lands (erosion rate 5 to 19.1 tons/acre ${ }^{-1}$ ). 
Table 3. Strategies for increasing carbon (C) sequestration using different land-management practices in croplands of the United States.

b. Mine land

c. Salt affected soils
Reclaim mine-spoil lands by re-vegetating with legumes, grasses, and woody plants; selection of species depends on climate. Application of an organic amendment is recommended for a long-term source of $\mathrm{N}$.

Use amendments (e.g., gypsum, organic matter, and green manure), leach salts out of the root zone, and choose crops with high salinity tolerance to improve above and below-ground biomass.
$2-7$

4-11

Total potential

$\mathrm{mmt}=$ million metric tons

Source: Lal et al. (1999) 